\title{
SYNTHESIS AND CHARACTERIZATION OF CERAMIC MEMBRANE FROM FLY ASH AND CLAY PREPARED BY SINTERING METHOD AT LOW TEMPERATURE
}

\author{
Selvie Diana ${ }^{1}$, Reza Fauzan ${ }^{1}$, Nasrul Arahman ${ }^{2,3,4,5, *}$, Fachrul Razi ${ }^{2}$ \\ and Muhammad Roil Bilad ${ }^{6}$ \\ ${ }^{1}$ Department of Chemical Engineering, Politeknik Negeri Lhokseumawe, \\ Lhokseumawe 24301, Indonesia. \\ ${ }^{2}$ Department of Chemical Engineering, Universitas Syiah Kuala, 23111, Banda Aceh, Indonesia. \\ ${ }^{3}$ Graduate School of Environmental Management, Universitas Syiah Kuala, Jl. Tgk Chik Pante \\ Kulu No.5, Darussalam, Banda Aceh, 23111, Indonesia \\ ${ }^{4}$ Research Center for Environmental and Natural Resources, Universitas Syiah Kuala, Jl. \\ Hamzah Fansuri, No.4, Darussalam, Banda Aceh, 23111Indonesia \\ ${ }^{5}$ Atsiri Research Center, Universitas Syiah Kuala, 23111, Banda Aceh, Indonesia \\ ${ }^{6}$ Department of Chemical Engineering, Universiti Teknologi Petronas, Perak 32610, Malaysia. \\ *E-mail: nasrular@unsyiah.ac.id
}

ABSTRACT

Ceramic membranes composed of fly ash-clay have been fabricated by using a sintering method at low temperatures. The membranes were made with a variety of fly ash composition of clay 35\%: 65\% (M1), 45\%: 55\% (M2), 50\%: 50\% (M3), 55\%: 45\% (M4), 65\%: 35\% (M5) at sintering temperatures of $900{ }^{\circ} \mathrm{C}$ and $1000^{\circ} \mathrm{C}$. The pore sizes, crystal structures, and membrane composition were analyzed by Scanning Electron Microscopy (SEM) and energy-dispersive X-ray (EDX), while the membrane phase composition was analyzed by X-Ray Diffraction (XRD). The SEM-data showed that the M5 membrane sintered at $1000{ }^{\circ} \mathrm{C}$ was classified as a microfiltration (MF) membrane with an average pore size of $0.6 \mu \mathrm{m}$. Based on the analysis using the X-Ray diffraction (XRD), the crystal structure of the membrane was dominated by the quartz phase $\left(\mathrm{SiO}_{2}\right)$ and illite $\left(\left(\mathrm{KH}_{3} \mathrm{O}\right) \mathrm{Al}_{2} \mathrm{Si}_{3} \mathrm{AlO}_{10}(\mathrm{OH})_{2}\right)$. It was also confirmed with EDX that the material is dominated by $\mathrm{O}, \mathrm{Si}$, and $\mathrm{Al}$ elements.

Keywords: Clay, Fly Ash, Ceramic Membrane, Low Temperature, Sintering.

(C) RASĀYAN. All rights reserved

\section{INTRODUCTION}

The ceramic membrane has been increasingly attracting the scientists for MF process due to its thermal, chemical and mechanical stability. This type of membrane is also known to have high separation efficiency compared to those in polymer membranes. ${ }^{1,2}$ The ceramic membranes are generally made from a variety of inorganic materials such as alumina ${ }^{3}$, silica, titania, and zirconia ${ }^{4}$. These inorganic materials could produce high-quality membranes. However, ceramic membranes are still considered less costeffective than the polymeric ones and persist as the main challenges for commercialization. To lower the production costs, a membrane from fly ash (a waste in cement industries) and clay (natural product) was developed in this study. The particle sizes of around $1.6 \mu \mathrm{m}-2 \mu \mathrm{m}$ of the fly ash and the clay are also very suitable for the fabrication of ceramic MF membrane. ${ }^{5}$

The fabrications of ceramic membranes from natural material such as fly ash and clay by using the sintering method have been studied. A fly ash ceramic membrane with an average pore size of $4.5 \mu \mathrm{m}$ via the sintering method at $1125^{\circ} \mathrm{C}$ has been successfully produced. ${ }^{6}$ Another study has reported a ceramic membrane with $42 \%$ porosity that was fabricated via the sintering method at $1100{ }^{\circ} \mathrm{C}{ }^{7}$ while the use of kaolin clay as the base material was selected to prepare ceramic membranes with a porosity and pore

Rasayan J. Chem., 13(3), 1335-1341(2020)

http://dx.doi.org/10.31788/RJC.2020.1335707

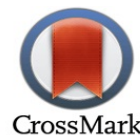


RASĀYAN J. Chem.

Vol. 13 | No. 3 |1335-1341| July - September | 2020

diameter of $27 \%$ and $0.73 \mu \mathrm{m}$, respectively. ${ }^{8}$ Clay material was also used as the base material for the fabrication of ceramic membranes with a pore size of $0.65 \mu \mathrm{m} .{ }^{9}$ Recycled fly ash and $\mathrm{Al}(\mathrm{OH})_{3}$ has also been reported as the base material and the resulting ceramic membrane has a pore size of $0.46 \mu \mathrm{m}$ at sintering temperature of $1300^{\circ} \mathrm{C} .{ }^{10}$

Based on the previous reports, clay and recycled fly ash have been used as effective base materials to fabricate ceramic membranes. However, no studies have reported their combination into one matrix composition to prepare the ceramic membrane. Therefore, this research aims to use the mixture of the fly ash and the clay as the base material for the manufacture of ceramic membranes with PVA as additive via the sintering method at low temperatures. The effect of the PVA additive on the properties of the fly ash/clay base membrane was analyzed via several analysis tools. The resulting membranes were characteristics in terms of morphological properties such as porosity, density, permeability, pore sizes and crystallinity. The variation of the fly ash-clay compositions were $35 \%$ : $65 \%$ (M1), $45 \%$ : 55\% (M2), 50\%: $50 \%$ (M3), 55\%: 45\% (M4), and 65\%: 35\% (M5).

\section{Materials}

\section{EXPERIMENTAL}

Fly ash and clay with a particle size of $125 \mu \mathrm{m}$ were used as the base materials for ceramic membrane fabrication. Fly ash samples were the waste produced in local cement manufacturing. The clay was purchased from PT. Rudang Jaya, Medan, Indonesia. Polyvinyl Alcohol (PVA) was purchased from Sigma, Aldrich.

\section{Synthesis of Fly Ash-Clay Membranes}

The compositions of fly ash-clay ratio were 35\%:65\% (M1), 45\%:55\% (M2), 50\%:50\% (M3), 55\%:45\% (M4) and 65\%;35\% (M5). For each sample, a total of 900 grams of the combined fly ash and clay were placed into a beaker glass. The particle size of fly ash and clay was set up constant for all membrane matrix as equal to 120 mesh filter. This mixture was then added with $4 \mathrm{wt} \%$ of polyvinyl alcohol (PVA) and $700 \mathrm{ml}$ of water to form a paste solution. To fabricate the membrane, a certain amount of paste was dropped onto a mold, followed by pressing the sample to remove air content. Afterward, the piece of the membrane was kept at room temperature for $7 \times 24$ hours. The sheet was then followed by the sintering process for 4 hours at 900 and $1000^{\circ} \mathrm{C}$ according to the procedure detailed elsewhere. ${ }^{5}$

\section{Characterization of Fly Ash-Clay Membrane}

Membrane density was obtained by weighing each membrane's, measuring the diameter and thickness, so that the membrane mass and volume of the membrane could be determined. Membrane density was calculated using Eq.-1.

$\rho=\frac{M(g r)}{V\left(c m^{3}\right)}$

Where $\rho, \mathrm{M}$, and $\mathrm{V}$ are the density $\left(\mathrm{gr} / \mathrm{cm}^{3}\right)$, the mass $(\mathrm{gr})$, and the volume of the membrane $\left(\mathrm{cm}^{3}\right)$, respectively. The porosity of each membrane was measured using the dry-wet method and calculated using Eq.-2.

$\varepsilon(\%)=\frac{W_{3}-W_{1}}{W_{3}-W_{2}}$

Where $W_{1}$ and $W_{2}$ represent the weight of dry and the wet of the membrane, respectively. $W_{3}$ is the weight of the membrane after filled with water for 48 hours.

The morphology and the element contained in the membrane matrix were analyzed using a Scanning Electron Microscope and an Energy Dispersive X-Ray (SEM-EDX, ZEISS2074, USA), respectively. The membrane phase composition was analyzed using x-ray diffraction (XRD, XRD7000, Shimadzu, Japan).

\section{Microfiltration Performance}

The filtration performance of the membrane was tested by flowing distilled water through the membrane module with an operating pressure of 0.5 bar. The permeability $\left(\mathrm{L} /\left(\mathrm{m}^{2} . \mathrm{hr}\right.\right.$.bar $\left.)\right)$ of the membrane was calculated based on Eq.-3. 
RASĀYAN J. Chem.

Vol. 13 | No. 3 |1335-1341| July - September | 2020

$P=\frac{V}{A t P}$

Where $\mathrm{V}$ represents the permeate volume $(\mathrm{L})$, A indicates the membrane surface area $\left(\mathrm{m}^{2}\right)$, $t$ indicates the filtration time (hour), and $\mathrm{P}$ represents the operating pressure used in the filtration process (bar).

\section{Porosity and Density of Fly Ash-Clay Membranes}

\section{RESULTS AND DISCUSSION}

The composition of membrane constituent materials and sintering temperature affects the diffusion process of particles that can be seen from the membrane porosity and density data. As seen in Fig.-1, the largest porosity of $45.86 \%$ is shown by M1 which was prepared at the sintering temperature of $900^{\circ} \mathrm{C}$. Membrane M1 (fly ash-clay 35\%: 65\%) had more clay in its composition, which can increase the number of pores and cavity on the membrane as also reported by others. ${ }^{11}$ In contrast, at $1000^{\circ} \mathrm{C}$ of the sintering process, the same clay composition yields a lower porosity even though it was still the highest among compositions within the same temperature. The increased temperature of sintering widens the contact area between the particles and the porous structure becomes more subtle, causing a space for porosity to also shrink. ${ }^{12}$

The sintering process is a process of compaction of powder material by forming the boundary bond between its constituent powders. Bonding between grain occurs due to thermal treatment with or without emphasis, and the temperature of the sintering is set below the melting point temperature of the constituent particles. The thermal treatment found in this process caused the diffusion between the constituent particles of the membrane in which the particles would interact to each other so that there was an increase in the constituent particle powder and contact plane between particles to form better state. ${ }^{13}$

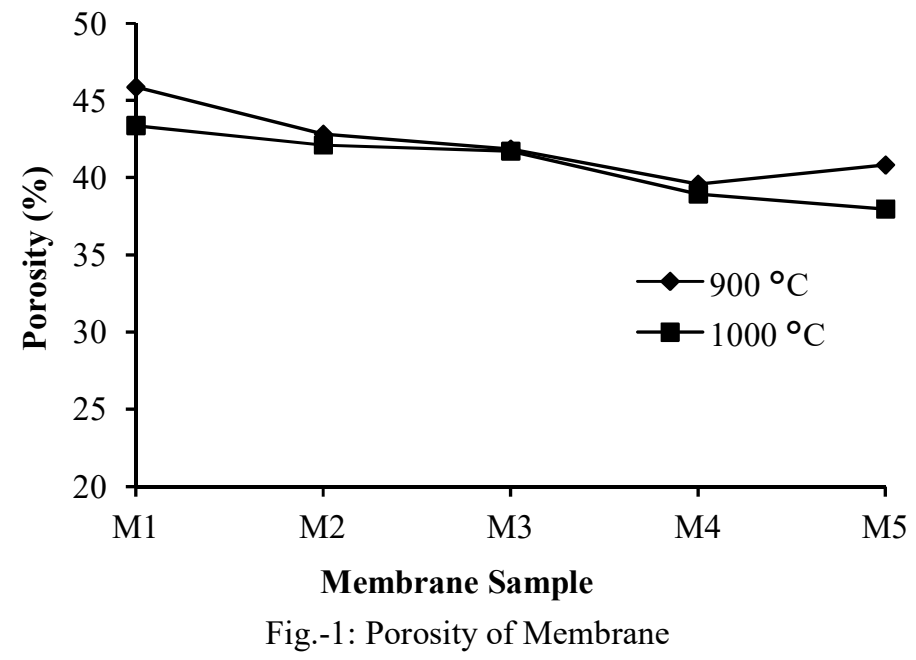

Figure-1 also shows that the lowest porosity of $38.97 \%$ poses by the M5 membrane (fly ash-clay $65 \%$ : $35 \%$ ) at a sintering temperature of $1000{ }^{\circ} \mathrm{C}$. The low porosity can be ascribed by the higher percentage of the fly ash that has a smaller particle size compared to the clay. This greatly affects the sintering process since increasing the number of small particles requires higher energy and increases the particle densities. ${ }^{13}$ Higher density eliminates the voids and thus reduces the porosity.

The membrane porosity also affects membrane density. As shown in Fig.-2, the largest density of 1.0048 $\mathrm{gr} / \mathrm{cm}^{3}$ belonged to the M5 membrane (fly ash-clay $65 \%: 35 \%$, at a sintering temperature $1000^{\circ} \mathrm{C}$ ). The smaller particle size of the fly ash compared to the clay causes particle thrusting energy to diffuse in a higher state. Therefore, the increasing interactions among particles create higher agglomerates density as detailed elsewhere. ${ }^{13}$ From Fig.-2, it can also be observed that the increase in temperature of sintering affected the process of growth and compaction of the particles. Higher sintering temperatures increase the resulting membrane density. 
RASĀYAN J. Chem.

Vol. 13 | No. 3 |1335-1341| July - September | 2020

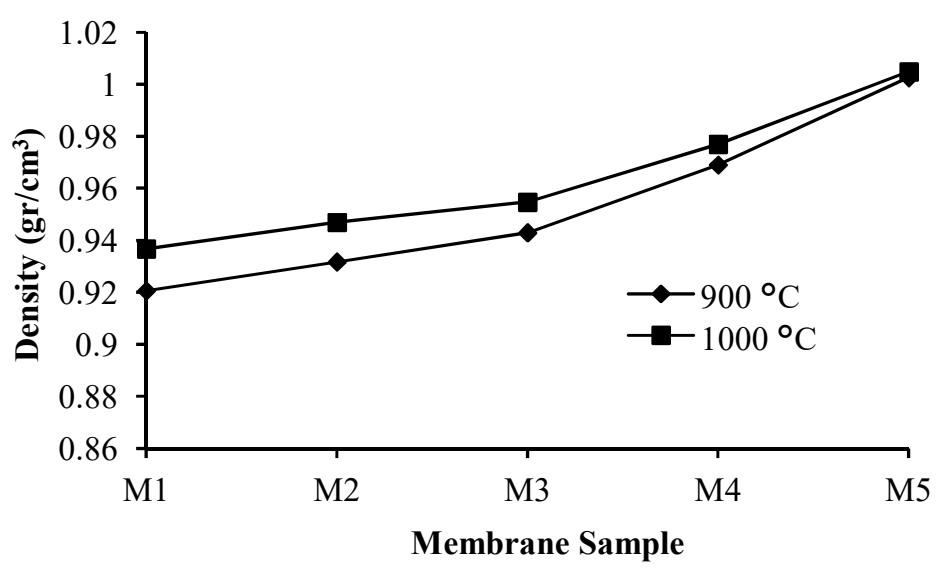

Fig.-2: Density of Membrane

\section{Structure, Pore Size, and Element of Fly Ash-Clay Membranes}

Figure-3 presents the structure of $\mathrm{M} 5$ membranes sintered at $900^{\circ} \mathrm{C}(4 \mathrm{a})$ and $1000^{\circ} \mathrm{C}(4 \mathrm{~b})$. At a sintering temperature of $900^{\circ} \mathrm{C}$, the porous structure dominated the membrane surface, but at a sintering temperature of $1000^{\circ} \mathrm{C}$, visible particles already formed a bond with one to another which reduced the porosity size to be shrinking drastically. The increase in sintering temperature from $900^{\circ} \mathrm{C}$ to $1000^{\circ} \mathrm{C}$ also causes smaller particles to melt and begin to form the neck of sintering. ${ }^{12}$
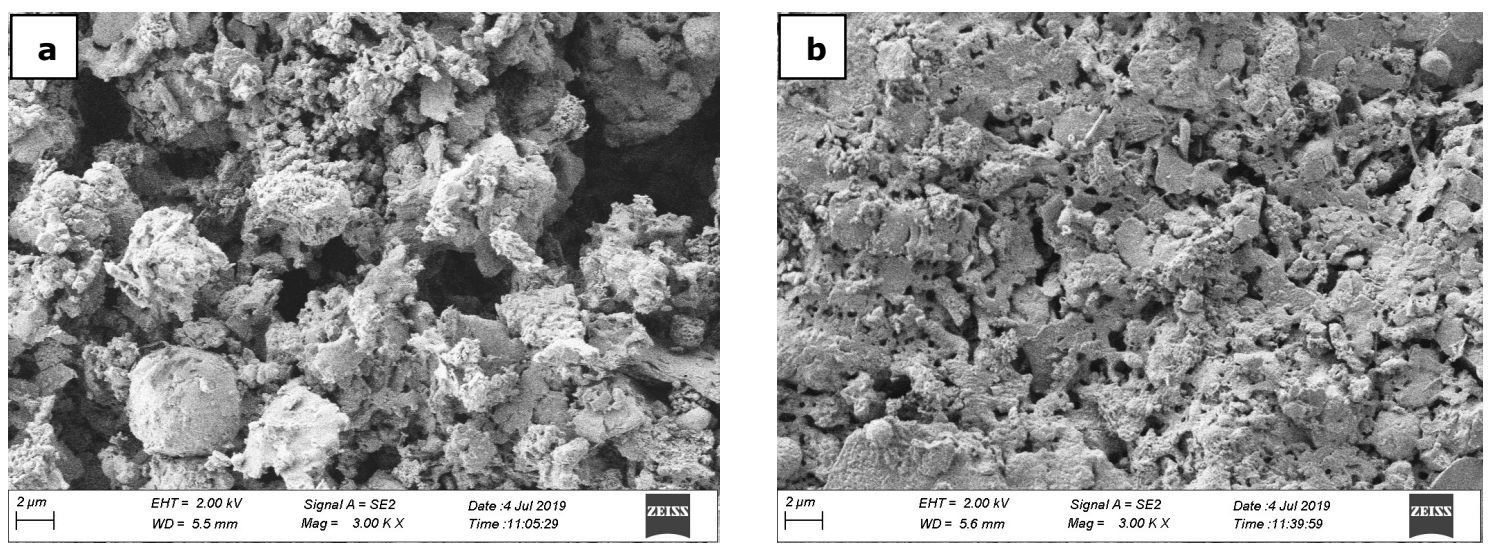

Fig.-3: The Structures of M5 Membranes sintered at $900{ }^{\circ} \mathrm{C}(\mathrm{a})$ and $1000{ }^{\circ} \mathrm{C}(\mathrm{b})$

Figure-4 presents the pore size of each membrane. The smallest pore size of $0.6 \mu \mathrm{m}$ is posed by the M5 membrane sintered at $1000^{\circ} \mathrm{C}$. The fly ash size has a smaller particle than clay and dominates the membrane composition of M5 which leads to a faster sintering process. This is caused by small particles having a faster sintering rate than larger particles. ${ }^{13}$ This then causes the rising grains within the particles which led to reduce pore formation and eventually reduces the pore size of the membrane.

Element composition analysis was performed by using an Energy Dispersive X-Ray (EDX) to the M5, the membrane with the smallest pore size sintered at $1000^{\circ} \mathrm{C}$. From Fig. -5 and Table-1, it can be seen that the main elements of the membrane consisted of $\mathrm{O}, \mathrm{Si}$, and $\mathrm{Al}$ of $40.94 \%, 20.71 \%$ and $16.40 \%$, respectively.

Table-1: Element Composition of M5 Membrane at Sintering Temperature $1000{ }^{\circ} \mathrm{C}$

\begin{tabular}{l|l|l|l|l|l|l|l|l|l|l|l|l}
\hline Element & CK & OK & NaK & MgK & AIK & SiK & SK & KK & CaK & TiK & FeK & Matrix \\
\hline Wt\% & 02.10 & 40.94 & 00.74 & 03.16 & 16.40 & 20.71 & 00.82 & 00.79 & 08.77 & 00.53 & 05.05 & Correction \\
\hline AT\% & 03.80 & 55.54 & 00.70 & 02.82 & 13.19 & 16.00 & 00.55 & 00.44 & 04.75 & 00.24 & 01.96 & ZAF \\
\hline
\end{tabular}


RASĀYAN J. Chem.

Vol. 13 | No. 3 |1335-1341| July - September | 2020

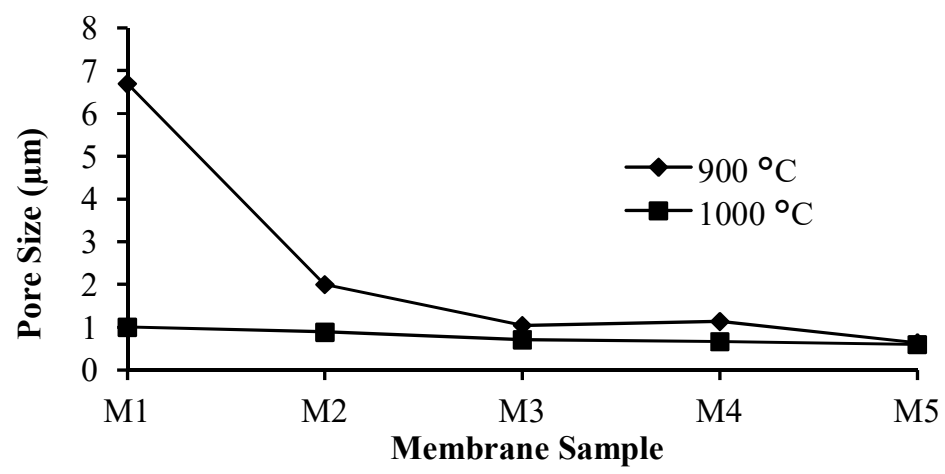

Fig.- 4: The Pore Size of Ceramic Membranes

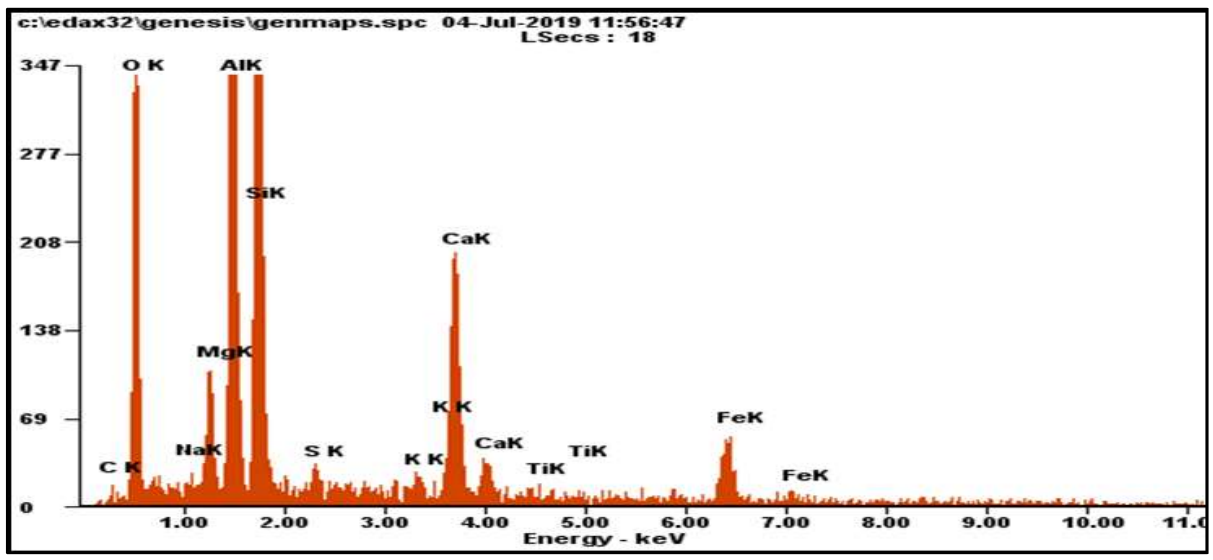

Fig.-5: The EDX Analysis of M5 Membrane at Sintering Temperature $1000{ }^{\circ} \mathrm{C}$

\section{The Crystal Structure of Fly Ash-Clay Membranes}

The results of XRD analysis in Fig.-6 show that the known fraction pattern of all membrane was predominantly quartz phase $\left(\mathrm{SiO}_{2}\right)$ and illite phase $\left(\left(\mathrm{KH}_{3} \mathrm{O}\right) \mathrm{Al}_{2} \mathrm{Si}_{3} \mathrm{Alo} 10(\mathrm{OH})_{2}\right)$. At a sintering temperature of $900^{\circ} \mathrm{C}$, there was still a diffraction pattern of the $\left(\mathrm{CaSO}_{4} .2 \mathrm{H}_{2} \mathrm{O}\right)$ phase of the $\mathrm{M} 2, \mathrm{M} 3$, and M4 membranes, whereas the graphite phase (C) was also visible on the M5 membrane. For the sintering temperature at $1000^{\circ} \mathrm{C}$, the phase $\left(\mathrm{CaSO}_{4} .2 \mathrm{H}_{2} \mathrm{O}\right)$ transformed into the $\mathrm{CaSO}_{4}$ anhydrite in the $\mathrm{M} 5$ membrane (Fig.- 6), while the graphite membrane C-phase was no longer formed. The process of mixing materials consisting of fly ash, clay, PVA caused irregularities in the decline of melting point, so at a temperature of $1000^{\circ} \mathrm{C}$, the phase $\mathrm{CaSO}_{4} \cdot 2 \mathrm{H}_{2} \mathrm{O}$ broke down into $\mathrm{CaSO}_{4}$ anhydrite and the graphite phase was not formed anymore. At a temperature of $1000^{\circ} \mathrm{C}$, the visible phase of $\mathrm{CaSiO}_{3}$ (wollastonite) has begun to form, which would stabilize at a temperature of $1120^{\circ} \mathrm{C}$ causes the formation of wollastonite phase at a lower intensity at $1000^{\circ} \mathrm{C}$ as also reported by others. ${ }^{14}$

Figure-7 presents the crystal size of ceramic membranes. The calculation of the $\mathrm{SiO}_{2}$ (quartz) crystal size that has the highest peak on each membrane was calculated based on the Debye-Scherrer equation. ${ }^{15} \mathrm{At}$ sintering temperature of $900^{\circ} \mathrm{C}$, the Average $\mathrm{SiO}_{2}$ crystal size was $16.602 \AA$ while at $1000^{\circ} \mathrm{C}$, the average temperature of $\mathrm{SiO}_{2}$ was accounted for $17.362 \AA$. The average size of crystals increased with the increasing sintering temperature due to the diffusion process between the particles contained in the membrane and the core reaction between the constituent atoms.

\section{Fly Ash-Clay Membrane Permeability}

Figure-8 presents the permeability of each membrane. The highest permeability of $415.75 \mathrm{Lm}^{-2} \mathrm{~h}^{-1} \mathrm{bar}^{-1}$ belonged to the M1 membrane prepared at the sintering temperature of $900{ }^{\circ} \mathrm{C}$. The high permeability can be ascribed by the high content of clay that promotes the formation of large pore size and high porosity. These materials can potentially be used to support filtration performance. The size of clay particles which 
RASĀYAN J. Chem.

Vol. 13 | No. 3 |1335-1341| July - September | 2020

were larger than fly ash also affected the flux value and membrane permeability, in which larger particle size caused the thrust of particles to diffuse to be limited. Consequently, the percentage of porosity is higher and the amount of permeate volume that passes through the membrane pore is also higher. ${ }^{16}$ This permeability tendency occurs in the same manner as polymeric membrane. ${ }^{17-18}$

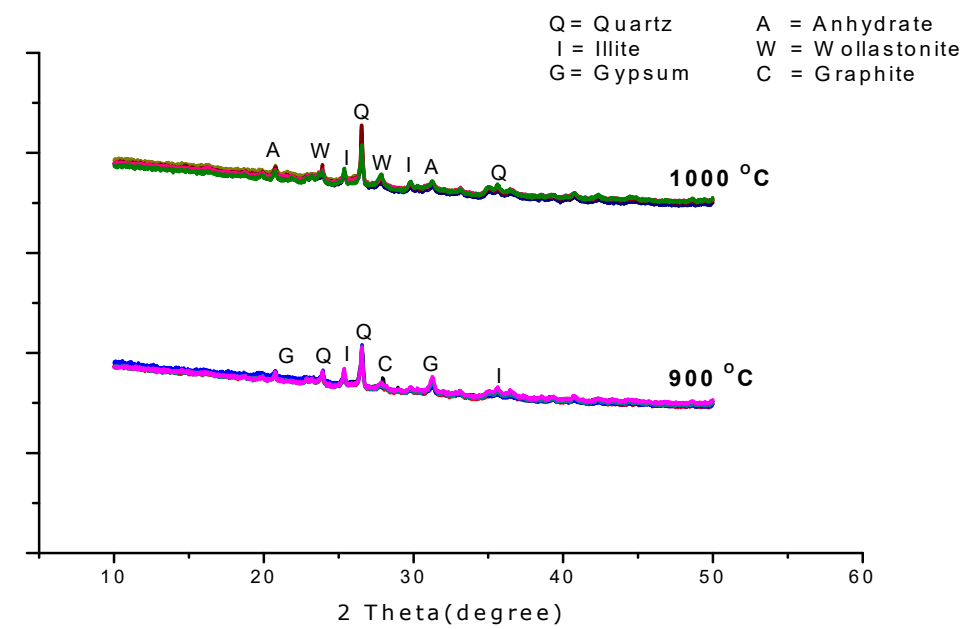

Fig.-6: The XRD Patterns of Fly Ash-Clay Membranes

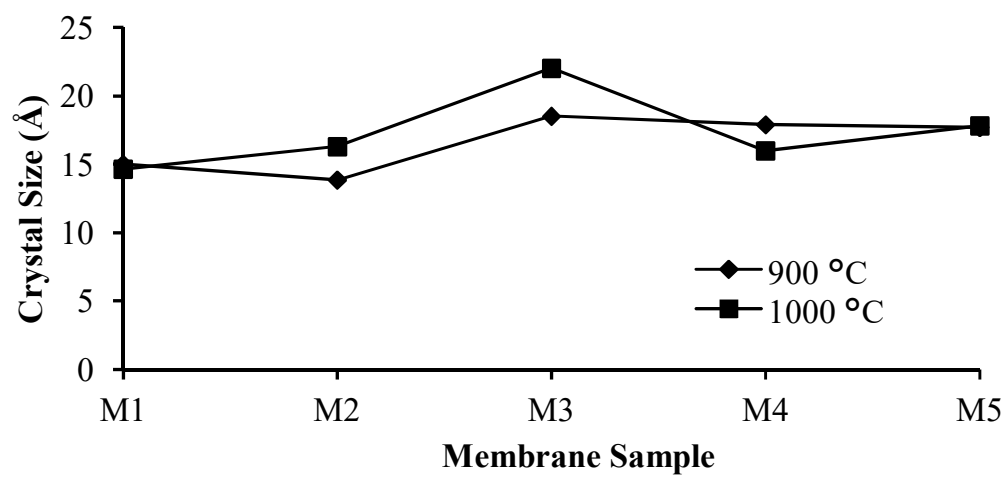

Fig.-7: The Crystal Size of Fly Ash-Clay Membranes

Lower permeability value of $92 \mathrm{Lm}^{-2} \mathrm{~h}^{-1}$ bar $^{-1}$ (Fig.-8) was achieved by the M5 membrane with a sintering temperature of $900^{\circ} \mathrm{C}$. The M5 membrane, which had more fly ash content, led to the decreased porosity levels, particularly in the pore sizes. The increased sintering temperature from $900^{\circ} \mathrm{C}$ to $1000^{\circ} \mathrm{C}$ also affected the diffusion process to be wider in the area and ultimately affecting the shrinking structure of the membrane porosity. The low membrane porosity caused the flux value and the permeability of the membrane to become low.

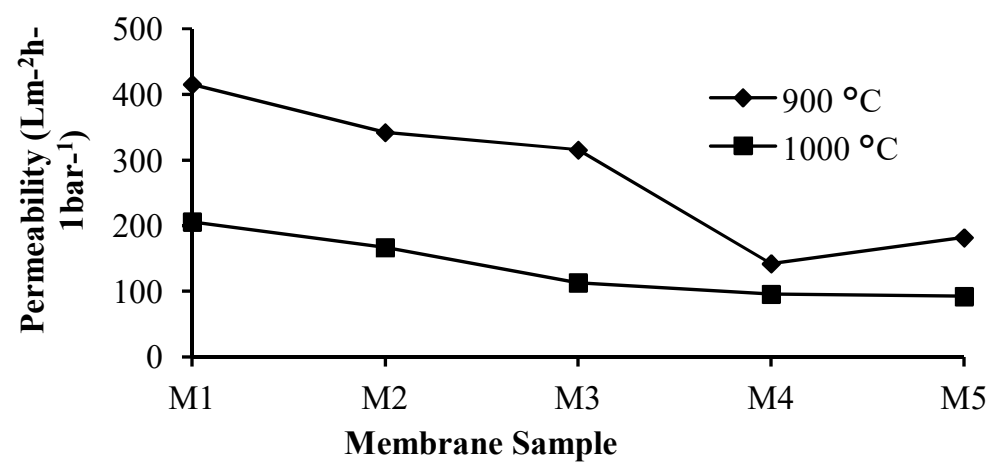

Fig.-8: Water Permeability 
RASĀYAN J. Chem.

Vol. 13 | No. 3 |1335-1341| July - September | 2020

\section{CONCLUSION}

Ceramic membranes from a mixture of fly ash and clay material have been successfully fabricated with various compositions and sintering temperatures. The membrane properties were achieved by membrane M5. It was made from fly ash-clay ratio of $65 \%: 35 \%$ at a sintering temperature of $1000^{\circ} \mathrm{C}$. The membrane has $38.97 \%$ of porosity, density $1.0048 \mathrm{gr} / \mathrm{cm}^{3}$, and permeability of $92 \mathrm{Lm}^{-2} \mathrm{~h}^{-1} \mathrm{bar}^{-1}$. Based on SEM image, it can be classified as a microfiltration membrane with an average pore size of $0.6 \mu \mathrm{m}$.

\section{ACKNOWLEDGMENT}

This research was funded by the Ministry of Research, Technology and Higher Education (KEMENRISTEK DIKTI) Republic of Indonesia in 2019. Our appreciation goes to the Director of Lhokseumawe State Polytechnic and Syiah Kuala University who have supported this research.

\section{REFERENCES}

1. G. Mustafa, K.Wyns, S.Janssens, A.Buekenhoudt and V.Meynen, Separation Purification Technology 193, 29(2018), DOI:10.1016/j.seppur.2017.11.015

2. A. Oun, N. Tahri, S. Mahouche-Chergui, B. Carbonnier, S. Majumdar, S. Sarkar, G.C.Sahoo, R.B. Amar, Separation Purification Technology, 188, 126(2017), DOI:10.1016/j.seppur.2017.07.005

3. J. Zhu, Y. Fan and N. Xu, Chinese Journal of Chemical Engineering, 18, 377(2010), DOI: 10.1016/S1004-9541(10)60234-0

4. Y. H. Wang, T. F. Tian, X. Q. Liu and G. Y. Meng, Journal of Membrane Science, 280, 261(2006), DOI: 10.1016/j.memsci.2006.01.027

5. S. Diana, R. Fauzan and E. Elfiana, In Proceedings of International Conference on Science and Innovated Engineering, Aceh, Indonesia, 012089, 1-7(2019), DOI:10.1088/1757-899X/536/1/012089

6. I. Jedidi, S. Khemakhem, S. Saidi, A. Larbot, N. Elloumi-Ammar, A. Fourati, A. Charfi, A. B. Salah, R.B.Salah, Powder Technology, 208, 427(2011), DOI:10.1016/ j.powtec.2010.08.039

7. M. Mouiya, A. Abourriche, A. Bouazizi, A. Benhammou, Y. El Hafiane, Y. Abouliatim, L.Nibou, M. Oumam, M. Ouammou, A. Smith, H. Hannache, Desalination, 427, 42(2018), DOI: $10.1016 /$ j.desal.2017.11.005

8. S. B. Rekik, J. Bouaziz, A. Deratani and S. Baklouti, Periodica Polytechnica Chemical Engineering, 61, 206(2017), DOI:10.3311/PPch.9679

9. C. M. Kumar, M. Roshni and D. Vasanth, Journal of Water Process Engineering, 29, 1000797 (2019), DOI:10.1016/j.jwpe.2019.100797

10. M. Fu, J. Liu, X. Dong, L. Zhu, Y. Dong and S. Hampshire, Journal of the European Ceramic Society, 39, 5320(2019), DOI:10.1016/j.jeurceramsoc.2019.08.042

11. M. Youmoue, R.T. Tene Fongang, J.C.Sofack, E. Kamseu, U. C. Melo, I.K. Tonle, C. Leonelli, S. Rossignol, Ceramics International, 43, 4496(2017), DOI:10.1016/ j.ceramint.2016.12.101

12. D. Zou, M. Qiu, X. Chen, E. Drioli and Y. Fan, Separation and Purification Technology, 210, 511(2019), DOI:10.1016/j.seppur.2018.08.040

13. R. M. German, Materials Science Forum, 835, 50(2016), DOI: $10.4028 /$ www. scientific.net/MSF.835.50

14. S. M. Salman, S. N. Salama and H. A. Abo-Mosallam, Journal of Asian Ceramics Societies, 3, 255(2015), DOI:10.1016/j.jascer.2015.04.004

15. S. M. Hosseini, N. Rafiei, A. Salabat and A. Ahmadi, Arabian Journal of Chemistry, 13(1), 2470(2020), DOI: 10.1016/j.arabjc.2018.06.001

16. E. Elfiana, S. Diana, A. Fuadi and R. Fauzan, In Proceedings of International Conference on Science and Innovated Engineering, Aceh, Indonesia, 012036, 1(2019), DOI:10.1088/1757899X/536/1/012036

17. S. Muchtar, S. Rajabzadeh, H. Matsuyama, M. Y. Wahab, R. Takagi, L. F. Fang, S. Mulyati, S. Jeon, N. Arahman, M. Riza, Journal of Applied Polymer Science, 136(14), 1(2018), DOI: 10.1002/app. 47312

18. S. Muchtar, M. Yusuf, S. Mulyati, S. Jeon, N. Arahman, M. Riza, Journal of Water Process Engineering, 28, 293(2019), DOI:10.1016/j.jwpe.2019.02.012

[RJC-5707/2019] 